\title{
Exendin-4 promotes proliferation and differentiation of MC3T3-E1 osteoblasts by MAPKs activation
}

\author{
Yingyu Feng', Lei Su², Xing Zhong33, Guohong Wei', Haipeng Xiao', Yanbing Li' and \\ Lingling Xiu ${ }^{1}$
}

'Department of Endocrinology, First Affiliated Hospital of Sun Yat-sen University, Guangzhou, People's Republic of China

2Department of Geriatrics, First Affiliated Hospital of Sun Yat-sen University, Guangzhou, People's Republic of China

3Department of Endocrinology, Second Affiliated Hospital of Anhui Medical University, Hefei, Anhui, People's Republic of China

Correspondence should be addressed to L Xiu

Email

xlingling58@163.com

\begin{abstract}
Glucagon-like peptide-1 (GLP1) and its receptor agonist have been previously reported to play a positive role in bone metabolism in aged ovariectomized rats and insulinresistant models. However, whether GLP1 has a direct effect on the proliferation and differentiation of osteoblasts or any cellular mechanism for this potential role is unknown. We examined the effects of the GLP1 receptor agonist exendin-4 on the proliferation, differentiation, and mineralization of mouse osteoblastic MC3T3-E1 cells. GLP1 receptor was detected in MC3T3-E1 cells by polymerase chain reaction (PCR) and Western blot assay. Cell proliferation was assessed using MTT assay, revealing that exendin-4 increased cell proliferation at effective concentrations between $10^{-10}$ and $10^{-5} \mathrm{M}$. Quantitative PCR analysis showed that exendin-4 increased the mRNA expression of the differentiation markers alkaline phosphatase (ALP), collagen-1 (COL1), osteocalcin (OC), and runt-related transcription factor 2 (RUNX2) under osteogenic conditions.

Alizarin red staining confirmed that $10^{-7} \mathrm{M}$ exendin-4 increased osteoblast mineralization by $18.7 \%$. Exendin-4 upregulated the phosphorylation of ERK1/2, p38, and JNK, with the peak effect at $1.5 \mathrm{~h}$ in the Western blot analysis. The use of selective MAPK inhibitors, namely PD98059, SB203580, and SP600125, blocked the effects of exendin-4 on kinase activation (ERK1/2, p38, and JNK), as well as cell proliferation and differentiation in MC3T3-E1 cells. These findings demonstrate that exendin-4 promotes both the proliferation and differentiation of preosteoblasts MC3T3-E1 via activation of the MAPK pathway.
\end{abstract} Key Words

Journal of Molecular

Endocrinology

(2016) 56, 189-199

\section{Introduction}

Diabetes mellitus and osteoporosis are both prevailing metabolic disorders and have been recently found to share similar molecular signatures. Multiple molecular factors that arise as a result of diabetes may lead to secondary osteoporosis (Kurra \& Siris 2011). In addition, patients with both diabetes and osteoporosis are increasingly 
common in an aging society (Viegas et al. 2011). The effects of antidiabetic agents on bone metabolism have thus received increased attention, especially in old diabetic patients with high fracture risk (Montagnani \& Gonnelli 2013). It has been reported that the novel incretin-based drugs, such as glucagon-like peptide-1 (GLP1) receptor agonist exenatide, did not affect bone mineral density despite body weight reduction in patients with type 2 diabetes mellitus (Bunck et al. 2011). This suggests that GLP1 and its receptor agonist may play a positive role in bone metabolism, but the specific mechanisms are still unclear.

GLP1 is one of the most important incretin hormones and is produced by intestinal L-cells. In vivo, GLP1 is degraded rapidly by dipeptidyl peptidase- 4 (DPP4) and has a very short half-life of $1 \sim 2 \mathrm{~min}$. Exendin-4, a natural GLP1 receptor (GLP1R) agonist, is extracted from the saliva of Gila monster (Heloderma suspectum). It shares $53 \%$ of its amino acid sequence with the N-terminal region of mammalian GLP1 and has an extra nine amino acid residues at its $C$ terminus. The difference in the second amino acid of GLP1 makes exendin- 4 become resistant to DPP-4 cleavage, therefore exendin-4 has a much longer half-life than GLP1, prompting its widespread use in in vitro studies (Yamada 2012). Exenatide is the synthetic product of exendin-4 for improving glycemic control.

Beyond its well-known effects on glucose metabolism and the protection of pancreatic beta cells, GLP1 has been reported to have extensive extrapancreatic effects on many other organs (Abu-Hamdah et al. 2009), with bone the latest target identified (Dicembrini et al. 2012). Animal studies show that GLP1 receptor-knockout mice develop osteoporosis (Yamada et al. 2008). GLP1 and exendin-4 can reverse the bone loss observed in insulinresistant and type 2 diabetic rats, and change their bone turnover markers, most likely through the PTH and Wnt pathways (Nuche-Berenguer et al. 2010a). In aged ovariectomized rats, exendin-4 can prevent osteopenia by promoting bone formation and suppressing bone resorption (Ma et al. 2013). Recently, specific functional GLP1 receptors have been identified on the cell membranes of mice MC3T3-E1 osteoblasts (Nuche-Berenguer et al. 2010b). These results strongly suggest that GLP1 and its receptor agonist may play a positive role in bone metabolism. However, the molecular pathway involved in such beneficial effects has not been elucidated, and how GLP1 and its analog may regulate osteoblast activity is still unknown.

Our study was designed to investigate the function of exendin-4 in mice preosteoblastic MC3T3-E1 cells, and illustrate the regulative mechanisms that exendin- 4 may serve in osteoblasts.

\section{Materials and methods}

\section{Reagents}

Chemicals including exendin-4, glycerol 2-phosphate disodium salt hydrate ( $\beta$-GP), ascorbic acid, 3-(4,5-dimethylthiazol-2-yl)-2,5-diphenyl-terazolium bromide (MTT), alizarin red, cetylpyridinium chloride, Trizol, and DMSO were purchased from Sigma. For Western blot analysis, rabbit anti-mouse-specific total and phospho (p)-p44/42 (Thr202/Tyr204), total and p-p38 (T180/ Y182), total and p-SAPK/JNK (Thr183/Tyr185) antibodies, $\alpha$-tubulin and GAPDH internal control antibodies, secondary antibody (goat anti-rabbit) and ERK inhibitor PD98059 and JNK inhibitor SP600125 were all purchased from Cell Signaling Technology, p38 inhibitor SB203580 was from Selleckchem (Houston, TX, USA). All other chemicals were of the highest grade available commercially.

\section{Cell culture}

MC3T3-E1 cells, a mouse preosteoblastic cell line, were kindly provided by Professor Eryuan Liao, Department of Metabolism and Endocrinology, The Second Xiangya Hospital, Central South University, Changsha, Hunan, People's Republic of China (Liang et al. 2013). MC3T3-E1 cells were cultured in DMEM-F12 medium (Gibco by Life Technologies, Shanghai, China) supplemented with $10 \%$ fetal bovine serum (FBS) and 1\% penicillin-streptomycin in $5 \% \mathrm{CO}_{2}$ at $37^{\circ} \mathrm{C}$. The culture media was replaced every 2 days. When the cell density reached approximately $80 \%$ confluence, the cells were treated with $0.25 \%$ trypsin and transferred to fresh culture flasks at 1:2 ratio.

\section{Differentiation of osteoblastic cells}

When the cells reached $80 \%$ confluence after 2 or 3 days of culture, they were induced to undergo differentiation using the osteogenic induction medium consisting of DMEM-F12, 10\% FBS, $1 \%$ penicillin-streptomycin, $50 \mathrm{mg} / \mathrm{L}$-ascorbic acid, and $10 \mathrm{mM} \beta$-GP. The medium was replaced every 2 days. Exendin-4 $(100 \mathrm{nM})$ was added in the experimental group to study its effect on osteoblasts.

\section{MTT assay for cell viability}

MC3T3-E1 cells were incubated in a 96-well plate with a cell density of $1 \times 10^{4}$ cells per well. The cells were then

Published by Bioscientifica Ltd. 
incubated with exendin-4 $\left(10^{-11} \sim 10^{-5} \mathrm{M}\right)$ for 24,48 , or $72 \mathrm{~h}$. The cells in the same volume of culture media were used as control. For inhibition experiments, cells were pretreated with the MAPK inhibitors: PD98059 (ERK1/2 inhibitor, $50 \mu \mathrm{M})$, SB203580 (p38 inhibitor, $10 \mu \mathrm{M})$, or SP600125 (JNK inhibitor, $50 \mu \mathrm{M}$ ), followed by culture with exendin-4 (100 nM) for $24 \mathrm{~h}$. Following treatments, the culture medium was removed, $10 \mu \mathrm{L}$ of freshly prepared MTT $(10 \mu \mathrm{g} / \mathrm{L})$ was added to each well of the plate, and the plates were placed in a cell incubator at $37^{\circ} \mathrm{C}$ for $4 \mathrm{~h} .150 \mu \mathrm{L}$ DMSO was added to each well and mixed thoroughly to lyse the cells and dissolve the dark blue crystals. After $5 \mathrm{~min}$ of dissolution, the absorbance was measured at $570 \mathrm{~nm}$ using a microplate reader (BioRad iMARK, CA, USA). Cell proliferation was assessed by calculating the relative cell viability, comparing the control and experimental groups.

\section{Real-time PCR for the detection of differentiation markers and GLP1R}

Gene expression of osteogenic differentiation markers including alkaline phosphatase (ALP), collagen-1 (COL1), osteocalcin (OC), and runt-related transcription factor-2 (RUNX2) in osteoblastic cells was quantified by fluorogenic quantitative PCR analysis. The MC3T3E1 cells were plated at $1 \times 10^{5}$ per well in 6-well plates and induced to differentiate in the absence or presence of exendin-4 (100 nM). The cells were also pretreated with or without the MAPK-specific inhibitors PD98059, SB203580, or SP600125 to see whether the effects of exendin-4 on MC3T3-E1 cells differentiation can be blocked. Total RNA from the cells was extracted on day $0,7,14$, 21 , and 28 using Trizol reagent. The integrity of total RNA was assessed by RNA agarose electrophoresis, and the concentration and purity of total RNA were determined with the absorbance at 260/280 nm (NANODROP 2000, Thermo, MA, USA). cDNA was synthesized from $2 \mu \mathrm{g}$ total RNA in a standard $20 \mu \mathrm{L}$ volume according to the protocol (ReverTra Ace qPCR RT Kit, Toyobo, Osaka, Japan). Real-time PCR amplification was performed with the ABI PRISM 7500 (Applied Biosystems). The $20 \mu \mathrm{L}$ PCR system consisted of $1 \mu \mathrm{L}$ cDNA, $0.3 \mu \mathrm{mol}$ forward primer, $0.3 \mu$ mol reverse primer, $10 \mu \mathrm{L}$ SYBR green qPCR mix, and $0.04 \mu \mathrm{L}$ ROX (SYBR qPCR Mix, Toyobo, Osaka, Japan). PCR primers (Table 1) were designed using Primer 5.0 software and, primers synthesis was acquired from Invitrogen Co. (Life Technologies). PCR conditions were as follows: $95^{\circ} \mathrm{C}$ for $10 \mathrm{~min}, 40$ cycles of the three-step PCR (denaturation at $95^{\circ} \mathrm{C}$ for $1 \mathrm{~min}$, annealing at $56^{\circ} \mathrm{C}$ for
$30 \mathrm{~s}$, and extension at $72^{\circ} \mathrm{C}$ for $\left.1 \mathrm{~min}\right)$. Expression of the EF1 $\alpha$ (Eef1 $\alpha$ ) (in differentiation experiments) and $\beta$-actin genes (in inhibition experiments) was used for normalization. The results were analyzed by the $2-\triangle \triangle \mathrm{Ct}$ method.

Glp1r mRNA was synthesized to cDNA and amplified by real-time polymerase chain reaction (RT-PCR) in $50 \mu \mathrm{L}$ volumes. The primers used for Glp1r (Pereira et al. 2015) was given in Table 1 . The amplification condition consisted of initial denaturation at $94^{\circ} \mathrm{C}$ for $5 \mathrm{~min}$, followed by 40 cycles of denaturation at $94^{\circ} \mathrm{C}$ for $1 \mathrm{~min}$, annealing at $58^{\circ} \mathrm{C}$ for $30 \mathrm{~s}$, and extension at $72^{\circ} \mathrm{C}$ for $1 \mathrm{~min}$. The products were visualized by electrophoresis on a $2 \%$ agarose gel. mRNA from mouse pancreas was used as a positive control. A mixture of water and loading buffer in equal proportion was used as a negative control.

\section{Alizarin red staining for mineralization}

To examine the mineralization of MC3T3-E1 cells, cells were plated in the differentiation medium at a concentration of $1 \times 10^{5}$ per well in 6-well plates in the presence or absence of $100 \mathrm{nM}$ exendin-4. After 21 days, the medium was removed and stained with alizarin red. The cells were washed with phosphate-buffered saline three times and fixed in $75 \%$ ethyl alcohol for $30 \mathrm{~min}$ at $4^{\circ} \mathrm{C}$. The cells were then washed with distilled water three times and stained in 1\% alizarin red solution ( $\mathrm{pH} 4.2$ ) for $30 \mathrm{~min}$ at $37^{\circ} \mathrm{C}$. Unbound dye was removed by washing several times with distilled water. Mineralized nodules were observed using a low magnification microscope and photographed. To quantify matrix mineralization, $1 \mathrm{~mL}$ $100 \mathrm{mM}$ cetylpyridinium chloride was added to each well and incubated for $1 \mathrm{~h}$ to dissolve and release the calciumbound alizarin red. The absorbance of released alizarin red was measured at $570 \mathrm{~nm}$.

Table 1 Primers used for fluorogenic quantitative RT-PCR.

\begin{tabular}{|c|c|c|}
\hline Name & Primer sequence & GenBank number \\
\hline$\beta$-actin & $\begin{array}{l}\text { 5'-TCTTGGGTATGGAATCCTGTG-3' } \\
\text { 5'-AGGTCTTTACGGATGTCAACG-3' }\end{array}$ & NM_007393.2 \\
\hline$E f 1 \alpha$ & $\begin{array}{l}\text { 5'-CTGAACCATCCAGGCCAAAT-3' } \\
\text { 5'-GGCTGTGTGACAATCCAG-3' }\end{array}$ & 10106.2 \\
\hline$A / p$ & $\begin{array}{l}\text { 5'-AACCCAGACACAAGCATTCC-3' } \\
\text { 5'-GAGAGCGAAGGGTCAGTCAG-3' }\end{array}$ & NM_007431.1 \\
\hline Col1 & $\begin{array}{l}\text { 5'-AGAGCATGACCGATGGATTC-3' } \\
\text { 5'-CCTTCTTGAGGTTGCCAGTC-3' }\end{array}$ & NM_007742.3 \\
\hline $\begin{array}{l}\text { OC } \\
\text { (Bglap2) }\end{array}$ & $\begin{array}{l}\text { 5'-TGCTTGTGACGAGCTATCAG-3' } \\
\text { 5'-GAGGACAGGGAGGATCAAGT-3' }\end{array}$ & NM_001032298.2 \\
\hline Runx2 & $\begin{array}{l}\text { 5'-AAGTGCGGTGCAAACTTTCT-3' } \\
\text { 5'-TCTCGGTGGCTGGTAGTGA-3' }\end{array}$ & NM_009820.2 \\
\hline Glp1r & $\begin{array}{l}\text { 5'-TCCTTCGTGAATGTCAGCTG-3' } \\
\text { 5'-TGGTGCAGTGCAAGTGTCTG-3' }\end{array}$ & $\begin{array}{l}\text { (Pereira et al. } \\
\text { 2015) }\end{array}$ \\
\hline
\end{tabular}

Published by Bioscientifica Ltd 
A

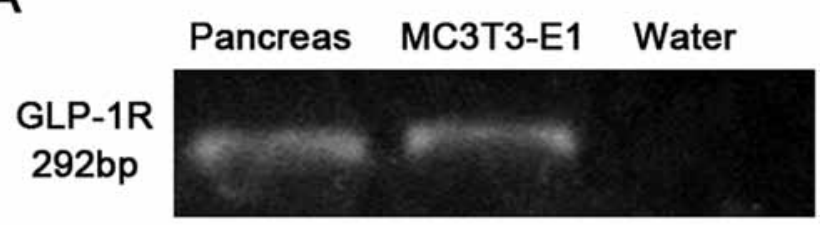

B

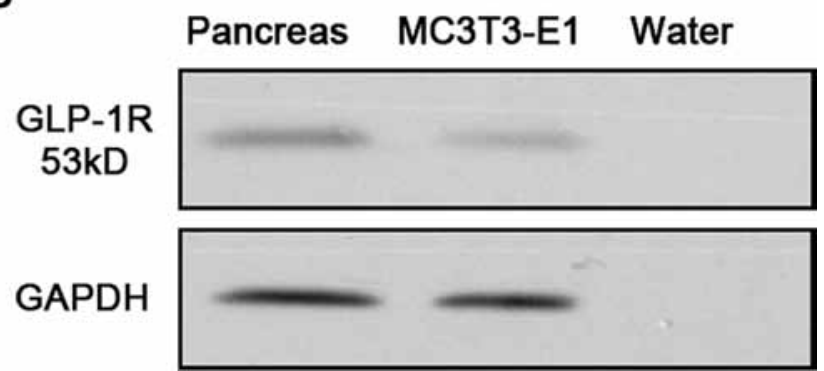

Figure 1

GLP1R was expressed in preosteoblastic MC3T3-E1 cells. (A) Expression of Glp1r mRNA in MC3T3-E1 cells and mouse pancreas. (B) GLP1 receptor protein was detectable in MC3T3-E1 cells by Western blot. Expression normalized to that of GAPDH. Equal parts of water and loading buffer were used as a negative control.

\section{Western blots for MAPK assays and GLP1R}

Western blot was used to detect the level of key proteins of MAPK assays including ERK1/2, p-ERK1/2, p38, p-p38, JNK, and p-JNK. House-keeping proteins $\alpha$-tubulin and GAPDH were used as internal controls for normalization. MC3T3-E1 cells were seeded in $30 \mathrm{~mm}$ culture dishes at the concentration of $1 \times 10^{6}$ per dish. After 2 days cultivation, the normal medium was replaced with low serum medium (containing 1\% FBS) and cultures were maintained for a further $12 \mathrm{~h}$. Then, the medium was changed and the cells were treated with $100 \mathrm{nM}$ exendin-4 for 15, 30, 60, 90, 120, 150, and $180 \mathrm{~min}$. For inhibition experiments, cells were pretreated with PD98059 $(50 \mu \mathrm{M})$, SB203580 $(10 \mu \mathrm{M})$, or SP600125 $(50 \mu \mathrm{M})$, followed by incubation with exendin-4 $(100 \mathrm{nM})$ for $1 \mathrm{~h}$. At the harvested time, cells were washed using PBS three times and lysed using the RIPA lysis system with phosphatase inhibitors (Beyotime Biotechnology, Shanghai, China). Ten micrograms of total protein were extracted from each sample, assessed by a BCA protein assay (Beyotime Biotechnology), then separated by 10\% SDSPAGE, and transferred onto a polyvinylidene difluoride (PVDF) membrane (Millipore). The membrane was blocked with 5\% non-fat milk in TBST (containing $50 \mathrm{mM}$ Tris$\mathrm{HCl}, 150 \mathrm{mM} \mathrm{NaCl}$, and 0.05\% Tween-20) and incubated overnight at $4^{\circ} \mathrm{C}$ with the specific primary antibodies: p-ERK1/2, total-ERK1/2, p-p38, total-p38, p-JNK, totalJNK diluted 1:1000. A horseradish peroxidase-conjugated secondary antibody (Cell Signaling Technology) at 1:2000 dilution was used for immunodetection and incubated for $1 \mathrm{~h}$ at room temperature. Lastly, the proteins were visualized by autoradiography using an enhanced chemiluminescence detection system (Thermo, Rockford, IL, USA). Protein bands on the films were quantified by ImageJ software (NIH).

Western blot analysis was also used to detect the specific expression of GLP1R protein in MC3T3-E1 cells, with protein from mouse pancreas used as a positive control. A mixture of water and loading buffer in equal proportion was used as a negative control. The anti-GLP1R antibody used was rabbit polyclonal (53 kDa) (ab39072, Abcam).

\section{Statistical analyses}

The data were expressed as means \pm standard deviation and analyzed by SPSS 16.0 software(IBM). Statistical evaluations for the differences between groups were performed by oneway ANOVA followed by the least significant differences test for post hoc multiple comparisons. Differences were considered to be significant at $P<0.05$.

\section{Results}

\section{Expression of GLP1R in MC3T3-E1 cells}

We investigated whether the GLP1R is present on preosteoblastic MC3T3-E1 cells by PCR and Western blot assay. Expression of the GLP1R in mouse pancreas was used as a positive control. As shown in Fig. 1, the specific GLP1R was expressed in undifferentiated MC3T3-E1 cells.

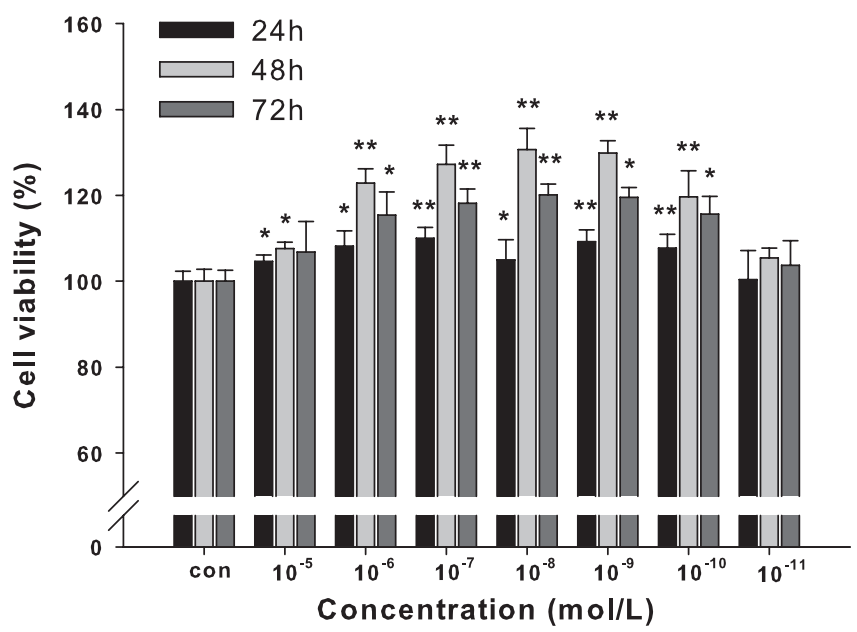

Figure 2

Effects of exendin-4 on cell viability in MC3T3-E1 cells. Cells were incubated with exendin-4 (10-11 $\left.\sim 10^{-5} \mathrm{M}\right)$ for 24,48 , or $72 \mathrm{~h}$. Results are represented as cell proliferation relative to the control $(n=3) . * P<0.05$, ** $P<0.01$ compared with the control group.

Published by Bioscientifica Ltd. 
A

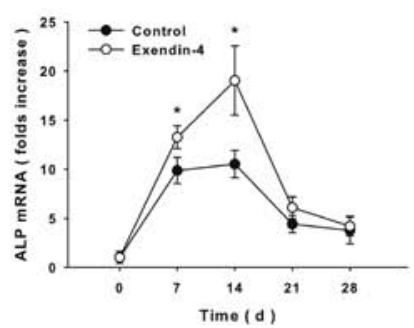

B

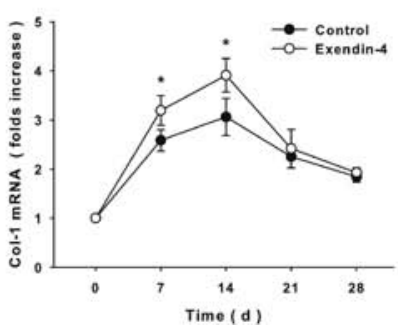

C

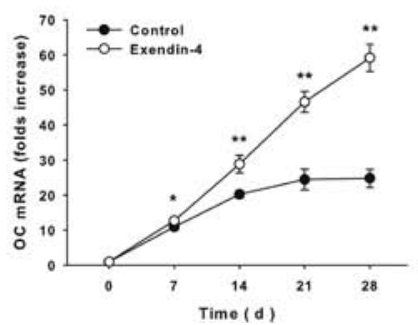

D

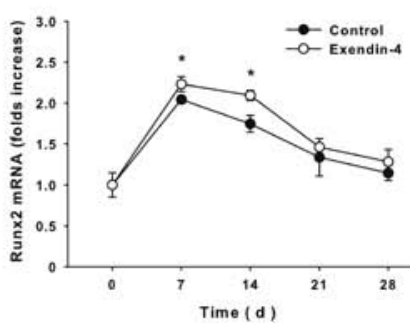

Figure 3

Effects of exendin-4 on the expression of differentiation markers in MC3T3-E1 cells. Cells were induced to differentiate in the presence or absence of exendin-4. Total RNA was collected on day $0,7,14,21$, and 28, fluorogenic quantitative PCR was used to evaluate the expressions of mRNA levels of Alp (A), Col1 (B), Oc (C), and Runx2 (D) $(n=3) .{ }^{*} P<0.05, * * P<0.01$ exendin-4 group vs control.

\section{Exendin-4 promoted cell proliferation in MC3T3-E1 cells}

The MTT assay showed that exendin-4 at concentrations of $10^{-10} \sim 10^{-5} \mathrm{M}$ led to a significant increase in cell viability (Fig. 2). The cell proliferation rate calculation showed the maximal effect of $10^{-7} \mathrm{M}(110 \pm 2.6 \%$ of the basal rate) and $10^{-8} \mathrm{M}(131 \pm 4.9 \%$ of the basal rate) at 24 and $48 \mathrm{~h}(P<0.05)$, respectively.

\section{Exendin-4 increased the gene expression of differentiation markers}

RT-PCR showed that osteogenesis markers increased rapidly following induction of osteogenesis by culturing in osteogenic media. The expression of mRNA encoding the transcription factor Runx 2 increased from a very early stage, peaking at day 7 before tapering off toward the end of the differentiation period. The expression of Alp and Col1 mRNA levels increased during the early and middle period, peaking at day 14 . The late-stage marker Oc continued to increase during the whole culture period, peaking at the end of osteogenesis (Fig. 3). These changes indicate that MC3T3-E1 cells differentiated into mature osteoblasts in the presence of osteogenic induction media. Compared with controls, exendin- 4 treatment significantly elevated the mRNA levels of Runx2, Alp, and Col1 on day 7 and 14 $(P<0.05)$. The maximum increases observed for each were 1.20-, 1.81- and 1.28-fold, respectively. Oc expression was increased by exendin- 4 throughout the entire differentiation period with the maximum increase of 2.38-fold occurring on day $28(P<0.05)$ (Fig. 3).

\section{Exendin-4 enhanced osteoblastic mineralization}

As shown in Fig. 4, mineralized nodules increased in MC3T3-E1 cells following the addition of differentiation factors into the medium $(50 \mathrm{mg} / \mathrm{L}$ ascorbic and $10 \mathrm{mM}$ $\beta$-GP). Larger nodules were observed by visual inspection and microscopic observation at low magnification in cells incubated with $100 \mathrm{nM}$ exendin-4. Consistent with this,

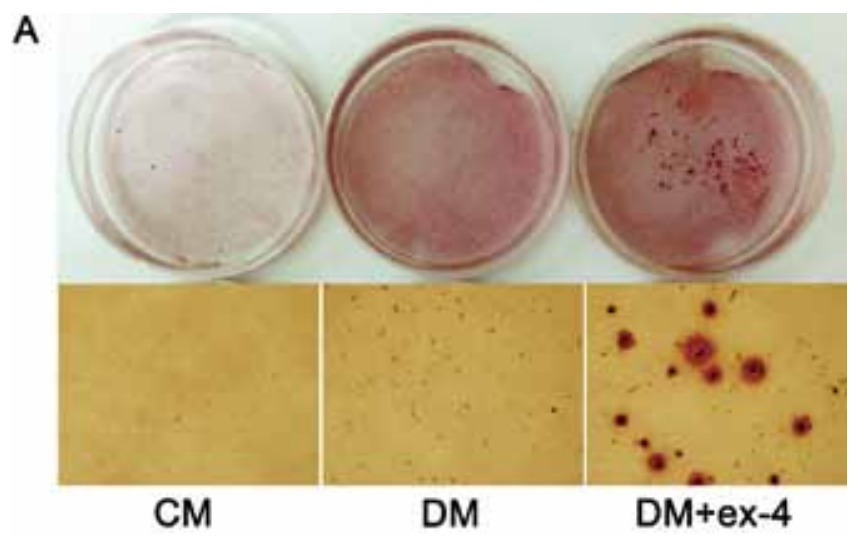

B

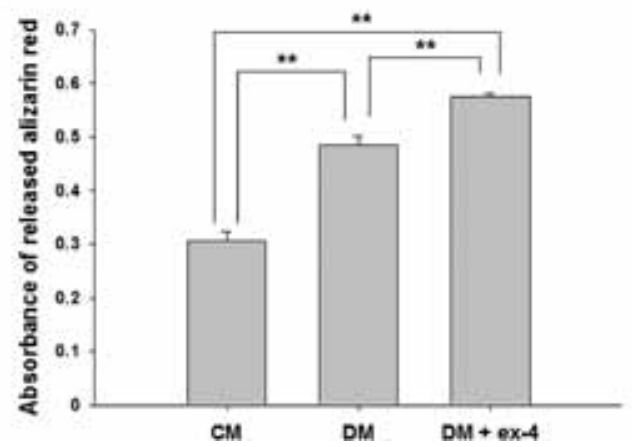

Figure 4

Mineralization of staining by Alizarin red in MC3T3-E1 cells. (A) Cells were cultured for 21 days in the control basal media (CM, left); differentiation media (DM, center); differentiation media with the addition of exendin-4 (right). Upper figures showed mineralized nodules by visual inspection and lower figures showed the photomicrograph (Magnification: $\times 40$ ). (B) Quantification by cetylpyridinium chloride dissolution and spectrophotometric readings $(n=3)$. ${ }^{*} P<0.05, * * P<0.01$.

Published by Bioscientifica Ltd. 

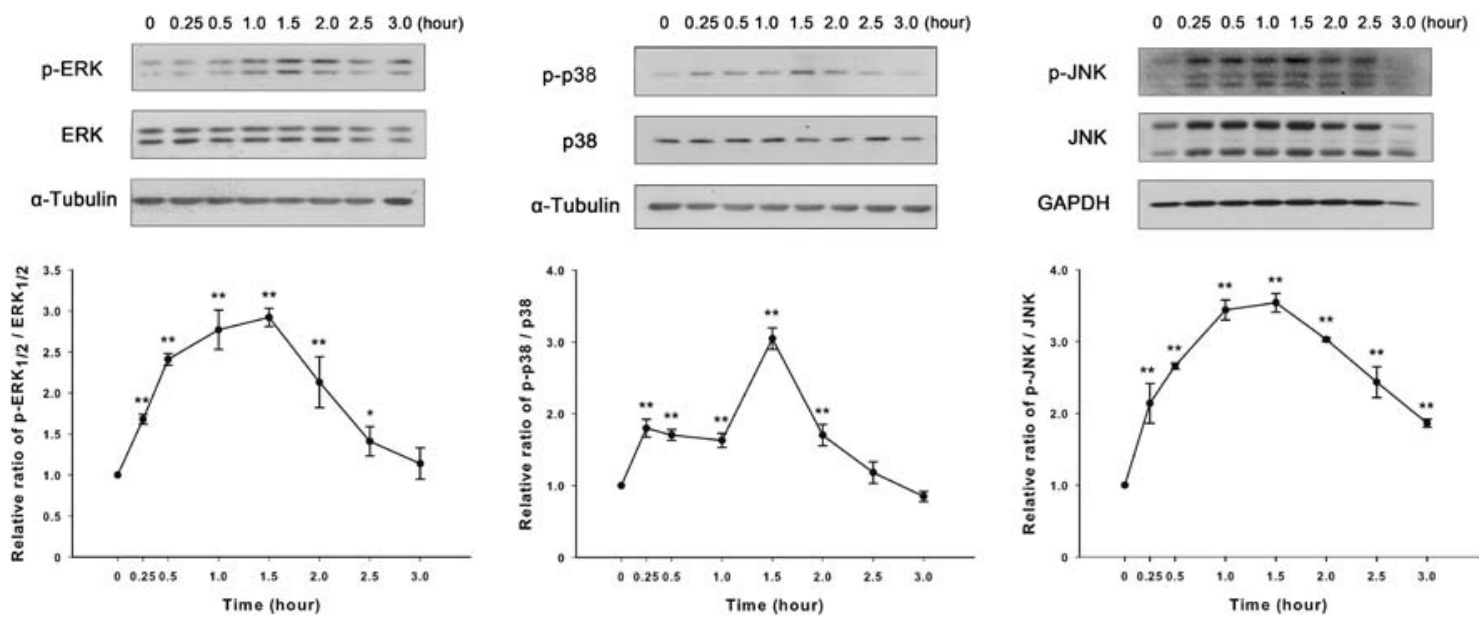

Figure 5

Effects of exendin-4 on MAPK phosphorylation in MC3T3-E1 cells. Cells were treated with exendin-4 and total proteins were extracted at different observed times to detect the phosphorylation of ERK1/2 (A), p38 (B), and JNK (C) $(n=3) .{ }^{*} P<0.05, * * P<0.01$ compared with $0 \mathrm{~h}$.

quantification of mineralization by cetylpyridinium chloride dissolution and spectrophotometry showed an $18.7 \%$ increase in mineralization in cells treated with exendin- 4 compared with cells cultured in differentiation media alone $(P<0.05)$.

\section{Exendin-4 induced the phosphorylation of MAPKs}

Exendin-4 increased the phosphorylation levels of all three MAPKs between 0.15 and $2.5 \mathrm{~h}$. The peak effects of exendin-4 on ERK1/2, p38, and JNK all appeared at $1.5 \mathrm{~h}$, which were $2.92 \pm 0.11-, 3.05 \pm 0.15-$, and $3.54 \pm 0.13$-fold of the baseline level, respectively $(P<0.05)$ (Fig. 5).

\section{Exendin-4-induced phosphorylation was abolished by MAPK inhibitors}

The upregulation of phosphorylation of MAPK induced by exendin- 4 was completely abolished by pretreatment

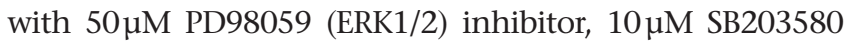
(p38 inhibitor), or 50 $\mu \mathrm{MSP} 600125$ (JNKinhibitor). Exendin-4 induced an increase in MAPK phosphorylation of ERK1/2,
A

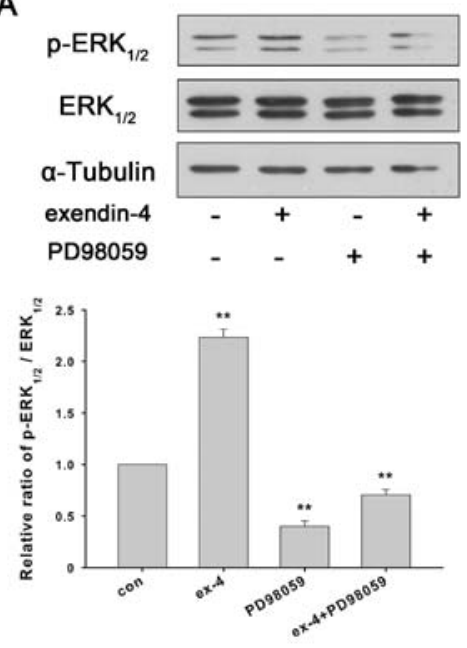

B

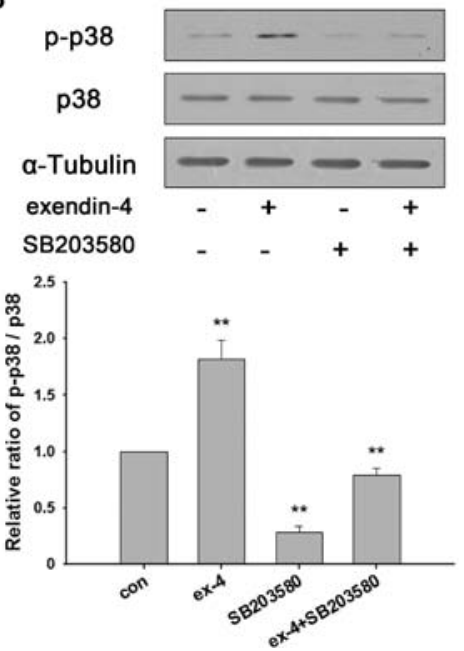

C

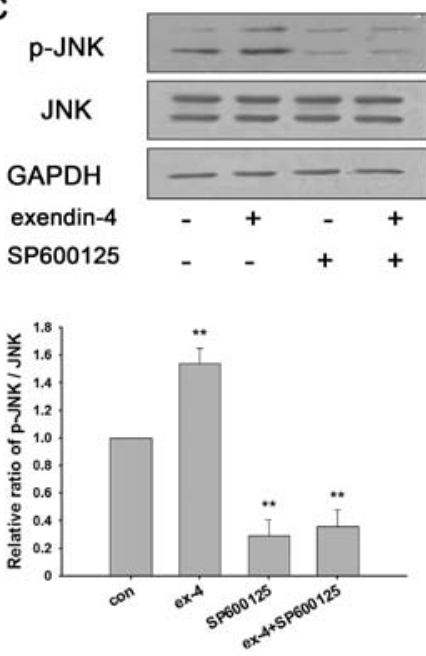

Figure 6

Effects of MAPK-selective inhibitors on exendin-4-induced upregulation of MAPK phosphorylation. Cells were pretreated with $50 \mu \mathrm{M}$ PD98059, $10 \mu \mathrm{M}$ SB203580, or $50 \mu \mathrm{M}$ SP600125 before incubation with $100 \mathrm{nM}$ exendin-4 for $1 \mathrm{~h}$. Total proteins were extracted to detect the phosphorylation of ERK1/2 (A), p38 (B), and JNK (C) $(n=3)$. ${ }^{*} P<0.05, * * P<0.01$ compared with the control group. 


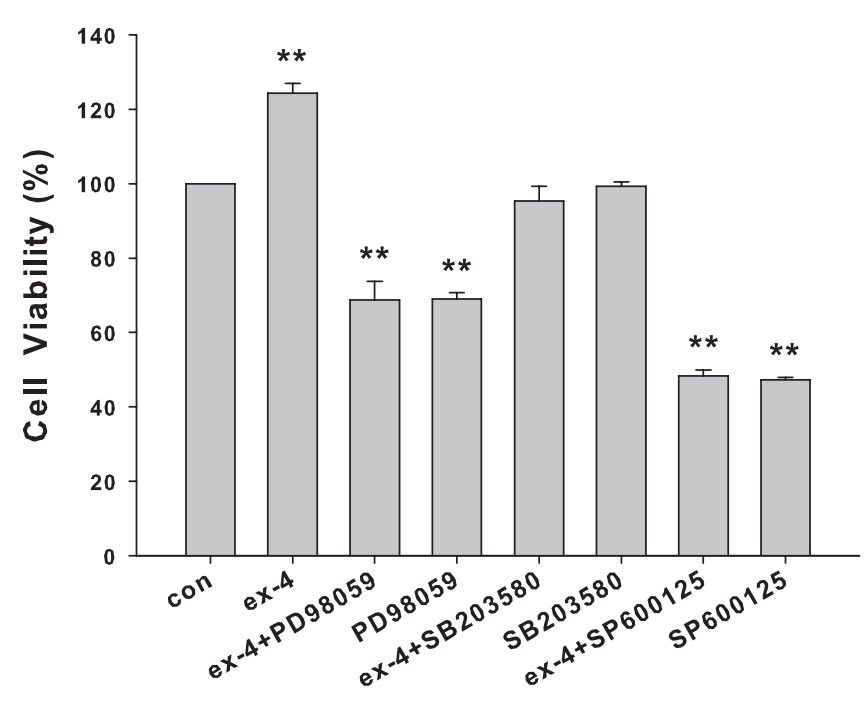

Figure 7

Effect of MAPK inhibitors on exendin-4-induced increase of MC3T3-E1 cell proliferation. Cells were pretreated with PD98058, SB203580, or SP600125 before incubation in the presence or absence of $100 \mathrm{nM}$ exendin-4, before performing MTT assays to analyze cell viability $(n=3)$. ${ }^{*} P<0.05, * * P<0.01$ compared with the control group.

p38, and JNK with $2.24 \pm 0.08-, 1.82 \pm 0.17-$, and $1.54 \pm 0.11$ fold $(P<0.01)$, respectively. Pretreatment with PD98059, SB203580, and SP600125 alone reduced the phosphorylation to $40.0 \pm 5.1 \%, 28.6 \pm 5.0 \%$, and $29.2 \pm 11.6 \% \quad(P<0.01)$, respectively, from control levels. Incubation of exendin- 4 and each inhibitor showed a lower activation at $70.5 \pm 5.2 \%$, $78.9 \pm 6.5 \%$, and $35.8 \pm 11.9 \%$, respectively, compared with the control group $(P<0.01)$ (Fig. 6).

\section{The effect of exendin-4 on MC3T3-E1 cells can be blocked by MAPK inhibitors}

To confirm that the MAPK pathways are involved in the exendin-4-induced osteoblast proliferation and differentiation, we used specific MAPK inhibitors to pretreat the cells.
The MTT assay showed that cells pretreated with PD98059 and SP600125 alone had only $69.0 \pm 1.7 \%$ and $47.3 \pm 0.6 \%$ cell viability in comparison with the controls $(P<0.01)$. Incubation with the p38 inhibitor SB203580 did not affect cell proliferation. Although incubation for $24 \mathrm{~h}$ with $100 \mathrm{nM}$ exendin- 4 increased the cell proliferation by $24.3 \pm 2.7 \%$, intervention using PD98059, SB203580, or SP600125 resulted in a reduction in cell viability of $55.6 \pm 5.0 \%, 31.6 \pm 2.9 \%$, and $76 \pm 1.5 \%$, respectively, compared with exendin-4 incubation alone $(P<0.05)$ (Fig. 7$)$.

The gene expression of osteoblastic differentiation markers in response to MAPK inhibitors was much lower than that in the controls. Exendin- 4 increased the mRNA levels of Alp, Col1, and Runx2 to 1.26 $\pm 0.21-, 1.18 \pm 0.03-$, and $1.23 \pm 0.09$-fold, respectively, at day 7 of differentiation $(P<0.05)$. PD98059 reduced all the mRNA levels of these markers whether treated with exendin- 4 or not; this was particularly apparent in the case of Runx 2 expression, which showed only $11-34 \%$ of the expression level compared with the control $(P<0.01)$. SB203580 also reversed the upregulation effect of exendin-4 on these markers; a most notable effect was seen for Alp with only $21.9 \pm 7.1 \%$ of control expression levels $(P<0.01)$. SP600125 likewise downregulated all the mRNA expressions, with the maximal effect of this inhibitor seen for Col1 expression with only $9.5 \pm 4.9 \%$ of the control levels when treated alone and $14.2 \pm 1.1 \%$ of the control level expression when used in conjunction with exendin-4 $(P<0.01)$ (Fig. 8).

\section{Discussion}

Our results demonstrated that the GLP1 receptor agonist exendin-4 exerted a direct effect on mice preosteoblast MC3T3-E1 cells. Signaling through this receptor resulted in the promotion of cell proliferation and an increase in the gene expression of osteogenic differentiation
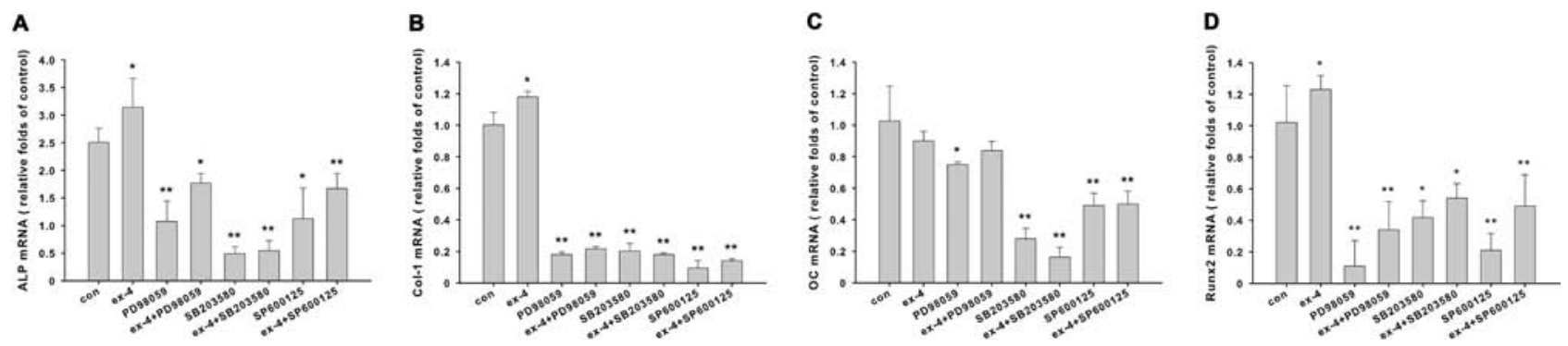

Figure 8

Effect of MAPK inhibitors on exendin-4-induced increase of MC3T3-E1 cell differentiation. Cells were switched to differentiation media, and pretreated with PD98058, SB203580, or SP600125 before their incubation in the presence or absence of 100 nM exendin-4. Total RNA was extracted at day 7 and quantitative PCR was performed $(n=3) .{ }^{*} P<0.05, * * P<0.01$ compared with the control group.

http://jme.endocrinology-journals.org DOI: 10.1530/JME-15-0264
C 2016 Society for Endocrinology Printed in Great Britain
Published by Bioscientifica Ltd 
markers. Exendin-4 also enhanced mineralization in preosteoblasts. Exendin-4 upregulated the activity of the MAPK signaling pathway, which is known to play a critical role in osteoblast differentiation and skeletal development. Taken together, these results imply that exendin-4 may play a positive role in bone metabolism by regulating the function of osteoblasts directly.

The gut-brain-bone axis has been recognized since the finding that bone turnover can occur as a response to feeding (Henriksen et al. 2003). The relationship between incretin and bone remains unclear. GLP1 has been found to have positive effects on bone metabolism in studies of cell lines (Sanz et al. 2010, Pacheco-Pantoja et al. 2011), gene-knockout mice (Yamada et al. 2008, Mieczkowska et al. 2015), and other animal models (Nuche-Berenguer et al. 2009, Nuche-Berenguer et al. 2010a, NucheBerenguer et al. 2011, Kim et al. 2013, Ma et al. 2013). Since GLP1 receptor agonists have been introduced in the pharmacological treatment of type 2 diabetes, their role in bone metabolism is now gaining increased attention.

Although GLP1 and exendin-4 have been proven to benefit the bone in different animal models, whether GLP1 and its receptor agonist can regulate the osteocytes directly has remained controversial. There is much confusion about whether GLP1R is expressed in osteocytes or not. Yamada et al. (2008) demonstrated that GLP1R ${ }^{-/-}$ mice have cortical osteopenia and bone fragility as well as increased osteoclastic numbers and bone resorption activity. While their study demonstrates the essential role of the murine GLP1R in control of bone resorption, Yamada and coworkers found that the GLP1R was absent in osteoblasts and GLP1 failed to increase intracellular cAMP levels in osteoblast Saos2 cells (Yamada et al. 2008). Furthermore, GLP1 had no effects on either osteoclastic differentiation or osteoblastic apoptosis protection, thus they concluded that GLP1 had no direct effect on osteocytes (Yamada et al. 2008). Nevertheless, recent studies have reported that the expression of GLP1R was detected in osteocyte-like MLO-Y4 cells by RT-PCR and Western blot analysis. In addition, GLP1R was present in the osteocytes taken from rat femur as determined by immunohistochemistry and immunofluorescence (Kim et al. 2013). These results indicate that the expression of GLP1R varied in different osteocyte cell lines and bone tissue. As in preosteoblast MC3T3-E1 cells, Nuche-Berenguer and co-workers identified the presence of a functional receptor for GLP1 by ${ }^{125}$ I-GLP1 binding studies. This GLP1R in MC3T3-E1 was different from those found previously in the pancreas and liver, as it failed to signal through cAMP. But GLP1R was undetectable in these cells by RT-PCR (Nuche-Berenguer et al. 2010b). In contrast, in our study, the expression of the GLP1R was detected by both RT-PCR and Western blot in preosteoblast MC3T3-E1 cells. In previous studies, Aoyama et al. (2014) showed that the expression of GLP1R was influenced by the glucose concentration in MC3T3-E1 cells undergoing differentiation induced by BMP2 (Aoyama et al. 2014). Another study found that GLP1R mRNA is absent in the pre-osteocytic cell line MLO-A5, but is present in the late osteocytic cell line IDG-SW3 as well as primary osteoblasts and osteoclasts derived from mouse bone marrow. Furthermore, they illustrated that the expression of GLP1R gradually diminishes as osteoblasts differentiate toward maturation (Pereira et al. 2015).

Taken together, we conclude that GLP1R is expressed in certain osteocytes including MC3T3-E1 cells, and is affected by several factors such as glucose concentration and different differentiation conditions. In addition, we found that exendin- 4 affects osteoblastic cell proliferation and differentiation as well as the kinase activity of MC3T3-E1 cells in vitro. This clearly shows that exendin-4 directly and functionally interacts with osteoblastic cells.

Recent reports have suggested that exendin- 4 has a direct osteogenic effect. In hyperlipidemic rats, both GLP1 and exendin-4 similarly reversed decreased bone mass in femurs and vertebrae (Nuche-Berenguer et al. 2011). In insulin-resistant and type 2 diabetic rats, exendin-4 exerted osteogenic effects and interacted with the Wnt pathway to promote bone formation (Nuche-Berenguer et al. 2009, Nuche-Berenguer et al. 2010a). Exendin-4 was also found to increase bone mineral density in type 2 diabetic OLETF rats through downregulation of SOST/sclerostin in osteocytes (Kim et al. 2013). More recently, exendin- 4 has been reported to prevent osteopenia by promoting bone formation and suppressing bone resorption in aged ovariectomized rats, confirming the effects of GLP1 on bone in an osteoporosis model (Ma et al. 2013). Our data indicate that exendin-4 promotes the proliferation of MC3T3-E1 osteoblastic cells at certain concentrations, suggesting that exendin-4 may increase the pool of basic osteocytes that can participate in bone formation. It is interesting that this response exhibits optimums at both intermediate concentrations and intermediate time of treatment. We inferred that these effects are probably owing to the saturability of the receptor. Most studies report that the effective concentrations of GLP1 or exendin-4 for different cell lines are between $10^{-9}$ and $10^{-6} \mathrm{M}$ (Sanz et al. 2010, Heller et al. 2011, Xie et al. 2014). Our results demonstrate a similar effective

Published by Bioscientifica Ltd. 
dosage range of exendin-4 for osteoblast proliferation, with a maximum effective dose of $10^{-7} \mathrm{M}$. The optimum treatment time of $48 \mathrm{~h}$ may be attributable to a number of factors, including the half-life of exendin- 4 and a corresponding decrease in bio-utilization of the drug, as well as increased cell apoptosis given the limited volume of the cell culture plates used in this study.

In addition, we found that exendin-4 treatment increases the expression of the transcriptional regulatory factor Run $x 2$ and dominant differentiation markers including Alp, Col1, and Oc. Mineralization was also improved at late-stage osteogenesis by exendin- 4 treatment, strongly suggesting that the GLP1 receptor agonist exendin-4 possibly enhances the osteogenic capability of osteoblasts to promote bone formation. Thus, we conclude that exendin-4 probably increases bone formation through the following mechanism: exendin-4 first promotes cell proliferation at early time points to increase the number of potential osteoblastic cells for bone formation. Exendin-4 treatment then upregulates the expression of differentiation markers and subsequently promotes osteoblast differentiation. This leads to an increase in the expression of bone-specific enzymes, collagen, and osteocalcin that accelerates cell mineralization and eventually promotes bone matrix formation.

To further explore the mechanisms of exendin- 4 on MC3T3-E1 osteoblastic cells, we explored the effect of exendin- 4 on kinase activation of the MAPK signaling pathway. MAPKs are classical signal transducers that are well characterized as mediators of cell growth, differentiation, apoptosis, and inflammation. MAPKs exert their effects through the ERK1/2, p38, JNK, and ERK5 pathways. Although the physiological role of the MAPK pathway in osteoblasts remains controversial, it has been determined as one of the most important regulatory signaling pathways in osteoblast proliferation and differentiation (Greenblatt et al. 2013). The activation of ERK1/2 has been shown to regulate the proliferation of bone marrow mesenchymal stem cells in vitro and accelerate their differentiation toward osteoblasts (Jaiswal et al. 2000, Miguel et al. 2005). The ERK pathway is associated with multiple key mediators of early- and late-stage osteoblast differentiation, including RUNX2, ATF4, IL1 $\beta$, and PTH-related protein (Franceschi et al. 2007, Greenblatt et al. 2013). Similar to ERK, the p38 pathway also can phosphorylate Runx2 to promote osteoblast differentiation (Greenblatt et al. 2010). Moreover, the p38 pathway has been reported to be necessary in multiple osteoblast differentiation induction studies (Guicheux et al. 2003, Zhou et al.
2007). The JNK pathway is typically involved in signaling stress response and inflammation, but has also been shown to operate in late-stage osteoblast differentiation (Matsuguchi et al. 2009, Hah et al. 2013).

In addition, numerous studies have showed that GLP1 and exendin- 4 affect the MAPK signaling pathway both in vivo and in vitro. GLP1 increased ERK1/2and p38-MAPK levels in pancreatic beta cells (INS 832/13), and the p38 inhibitor SB203580 suppressed GLP1-induced beta cell proliferation (Buteau et al. 2001). In human myocytes, GLP1 and exendin- 4 both activated ERK1/2 and MAPK, and stimulated glucose uptake, while the ERK1/2 inhibitor PD98059 abolished this effect (Gonzalez et al. 2005). Similar effects were observed in normal human adipocytes (Sancho et al. 2007). Hindbrain administration of exendin- 4 increased MAPK activity that contributed to food intake regulation and body weight suppression in SD rats (Hayes et al. 2011). However, in peripheral blood mononuclear cells from type 2 diabetes patients, exendin- 4 downregulated ERK and p38 MAPK phosphorylation to reduce oxidative stress and pro-inflammatory responses (He et al. 2013). In osteocytes, GLP1 induced a clear increase in the phosphorylation of ERK1/2 MAPKs in MC3T3E1 cells (Nuche-Berenguer et al. 2010b). Therefore, we believe that the activity of MAPKs participates in the mechanism of exendin- 4 to promote both proliferation and differentiation in MC3T3-E1 cells and undertook further experiments to test this hypothesis.

Our results show that exendin- 4 activates the three MAPKs within a short time period, all with a peak increase of phosphorylation at $1.5 \mathrm{~h}$ from the beginning of treatment. However, use of the specific inhibitors PD98059, SB203580, and SP600125 blocked exendin-4 signaling through ERK1/2, p38, and JNK, respectively. This demonstrates that exendin- 4 can activate the MAPK pathways in MC3T3-E1 cells.

The use of specific MAPK inhibitors confirmed the necessary role that MAPKs play in osteoblastic cell proliferation and differentiation. The use of the ERK1/2 inhibitor PD98059 resulted in the reduced proliferation of MC3T3-E1 cells and a decrease in the expression of differentiation markers, in particular Runx2. This is consistent with previous studies that have shown that ERKMAPK modulates osteocyte function by regulating the activity of Runx2 (Ge et al. 2007, Ge et al. 2009). We have also shown that treatment with SB203580, an inhibitor of $\mathrm{p} 38$, did not affect osteoblast proliferation but showed marked inhibitory effects on cellular differentiation, with the greatest decreases seen in Alp mRNA expression.

Published by Bioscientifica Ltd 
The JNK inhibitor SP600125 used in our experiments also inhibited cell growth and differentiation, as expected.

Finally, the expression profiles of osteoblastic markers and cell viability data suggest that the effects of exendin-4 in promoting osteoblast proliferation and differentiation can be prevented by inhibiting MAPK pathways. In proliferation experiments, exendin- 4 incubation in the presence of PD98059 and SP600125 confers much lower cell viability compared with controls, but similar to the group using each inhibitor only. This suggests that the effects of exendin-4 on MC3T3-E1 cells proliferation require ERKand JNK-MAPK. The upregulation effects of osteoblastic markers induced by exendin- 4 were abolished partly or completely by each MAPK-specific inhibitor, suggesting that blocking each MAPK pathway attenuates the effects of exendin- 4 on cell differentiation.

Thus, we suggest that the effects of exendin- 4 on osteoblast proliferation and differentiation are dependent on MAPK activation. In previous studies performed in the same cell line, Nuche-Berenguer and his team found that $10^{-8}$ M GLP1 downregulates the gene expression of Runx2 after $24 \mathrm{~h}$ of treatment as well as 5 days of osteogenesis induction (Nuche-Berenguer et al. 2010b). Our results show that $10^{-7} \mathrm{M}$ exendin- 4 treatment mildly elevated the same gene levels, but during a much longer differentiation period of 7-28 days. As both ERK1/2 and p38 can phosphorylate Runx 2 and regulate its activity, we thought that differential transcription of Runx 2 may be involved in exendin-4-induced osteoblast differentiation. However, the cross-talk among MAPK pathways and their interaction with other critical signaling pathways in osteoblasts require further exploration.

In conclusion, we demonstrate for the first time the effects of the GLP1 receptor agonist exendin-4 on the preosteoblastic MC3T3-E1 cells. Exendin-4 can promote the proliferation and differentiation of MC3T3-E1 cells, partly via the activation of MAPK signaling pathways. This study provides evidence that exendin- 4 plays a positive role in bone metabolism by promoting bone formation. With further study, future consideration of GLP1 receptor agonists as a treatment for bone health in diabetes patients, particularly those with osteoporosis, may be an option. Given the large number of patients treated with GLP1 receptor agonists, more studies are needed to understand the precise role that GLP1 plays in bone metabolism.

\section{Declaration of interest}

All the authors declare that there is no conflict of interest that could be perceived as prejudicing the impartiality of the research reported.

\section{Funding}

The work was supported by grants from Natural Science Foundation of Guangdong Province (S2011010004368; S2012040007756) and Natural Science Foundation of China (No. 81272932).

\section{Author contribution}

$\mathrm{LX}$ and HX designed the study design; YF conducted the study; YF, XZ, and, GW involved in data collection and analysis; YF drafted the manuscript; $L S$ and $Y L$ revised the manuscript content; $Y F, L S, X Z, G W, H X, Y L$, and $L X$ approved the final version of manuscript; And YF takes responsibility for the integrity of the data analysis.

\section{References}

Abu-Hamdah R, Rabiee A, Meneilly GS, Shannon RP, Andersen DK \& Elahi D 2009 Clinical review: the extrapancreatic effects of glucagon-like peptide-1 and related peptides. Journal of Clinical Endocrinology and Metabolism 94 1843-1852. (doi:10.1210/ jc.2008-1296)

Aoyama E, Watari I, Podyma-Inoue KA, Yanagishita M \& Ono T 2014 Expression of glucagon-like peptide-1 receptor and glucosedependent insulinotropic polypeptide receptor is regulated by the glucose concentration in mouse osteoblastic MC3T3-E1 cells. International Journal of Molecular Medicine 34 475-482. (doi:10.3892/ijmm.2014.1787)

Bunck MC, Eliasson B, Corner A, Heine RJ, Shaginian RM, Taskinen MR, Yki-Jarvinen H, Smith U \& Diamant M 2011 Exenatide treatment did not affect bone mineral density despite body weight reduction in patients with type 2 diabetes. Diabetes, Obesity \& Metabolism 13 374-377. (doi:10.2337/dc11-0291)

Buteau J, Foisy S, Rhodes CJ, Carpenter L, Biden TJ \& Prentki M 2001 Protein kinase Czeta activation mediates glucagon-like peptide-1induced pancreatic beta-cell proliferation. Diabetes 50 2237-2243. (doi:10.2337/diabetes.50.10.2237)

Dicembrini I, Mannucci E \& Rotella CM 2012 Bone: incretin hormones perceiver or receiver? Experimental Diabetes Research 2012519784. (doi:10.1155/2012/519784)

Franceschi RT, Ge C, Xiao G, Roca H \& Jiang D 2007 Transcriptional regulation of osteoblasts. Annals of the New York Academy of Sciences 1116 196-207. (doi:10.1074/jbc.M109.040980)

Ge C, Xiao G, Jiang D \& Franceschi RT 2007 Critical role of the extracellular signal-regulated kinase-MAPK pathway in osteoblast differentiation and skeletal development. Journal of Cell Biology 176 709-718. (doi:10.1074/jbc.M109.040980)

Ge C, Xiao G, Jiang D, Yang Q, Hatch NE, Roca H \& Franceschi RT 2009 Identification and functional characterization of ERK/MAPK phosphorylation sites in the Runx2 transcription factor. Journal of Biological Chemistry 284 32533-32543. (doi:10.1074/jbc. M109.040980)

Gonzalez N, Acitores A, Sancho V, Valverde I \& VillanuevaPenacarrillo ML 2005 Effect of GLP-1 on glucose transport and its cell signalling in human myocytes. Regulatory Peptides 126 203-211. (doi:10.1530/JME-11-0127)

Greenblatt MB, Shim JH \& Glimcher LH 2013 Mitogen-activated protein kinase pathways in osteoblasts. Annual Review of Cell and Developmental Biology 29 63-79. (doi:10.1146/annurev-cellbio-101512-122347)

Greenblatt MB, Shim JH, Zou W, Sitara D, Schweitzer M, Hu D, Lotinun S, Sano Y, Baron R, Park JM et al. 2010 The p38 MAPK pathway is essential for skeletogenesis and bone homeostasis in mice. Journal of Clinical Investigation 120 2457-2473. (doi:10.1172/JCI42285)

Guicheux J, Lemonnier J, Ghayor C, Suzuki A, Palmer G \& Caverzasio J 2003 Activation of p38 mitogen-activated protein kinase and c-Jun-NH2-terminal kinase by BMP-2 and their implication in the http://jme.endocrinology-journals.org

DOI: 10.1530/JME-15-0264
() 2016 Society for Endocrinology Printed in Great Britain 
stimulation of osteoblastic cell differentiation. Journal of Bone and Mineral Research 18 2060-2068. (doi:10.1359/jbmr.2003.18.11.2060)

Hah YS, Kang HG, Cho HY, Shin SH, Kim UK, Park BW, Lee SI, Rho GJ, Kim JR \& Byun JH 2013 JNK signaling plays an important role in the effects of TNF-alpha and IL-1beta on in vitro osteoblastic differentiation of cultured human periosteal-derived cells. Molecular Biology Reports 40 4869-4881. (doi:10.1007/s11033-013-2586-3)

Hayes MR, Leichner TM, Zhao S, Lee GS, Chowansky A, Zimmer D, De Jonghe BC, Kanoski SE, Grill HJ \& Bence KK 2011 Intracellular signals mediating the food intake-suppressive effects of hindbrain glucagon-like peptide-1 receptor activation. Cell Metabolism 13 320-330. (doi:10.1016/j.cmet.2011.02.001)

He L, Wong CK, Cheung KK, Yau HC, Fu A, Zhao HL, Leung KM, Kong AP, Wong GW, Chan PK et al. 2013 Anti-inflammatory effects of exendin-4, a glucagon-like peptide-1 analog, on human peripheral lymphocytes in patients with type 2 diabetes. Journal of Diabetes Investigation 4 382-392. (doi:10.1111/jdi.12063)

Heller C, Kuhn MC, Mulders-Opgenoorth B, Schott M, Willenberg HS, Scherbaum WA \& Schinner S 2011 Exendin-4 upregulates the expression of Wnt-4, a novel regulator of pancreatic beta-cell proliferation. American Journal of Physiology: Endocrinology and Metabolism 301 E864-872. (doi:10.1152/ajpendo.00144.2011)

Henriksen DB, Alexandersen P, Bjarnason NH, Vilsboll T, Hartmann B, Henriksen EE, Byrjalsen I, Krarup T, Holst JJ \& Christiansen C 2003 Role of gastrointestinal hormones in postprandial reduction of bone resorption. Journal of Bone and Mineral Research 18 2180-2189.

Jaiswal RK, Jaiswal N, Bruder SP, Mbalaviele G, Marshak DR \& Pittenger MF 2000 Adult human mesenchymal stem cell differentiation to the osteogenic or adipogenic lineage is regulated by mitogen-activated protein kinase. Journal of Biological Chemistry 275 9645-9652. (doi:10.1074/jbc.275.13.9645)

Kim JY, Lee SK, Jo KJ, Song DY, Lim DM, Park KY, Bonewald LF \& Kim BJ 2013 Exendin-4 increases bone mineral density in type 2 diabetic OLETF rats potentially through the down-regulation of SOST/sclerostin in osteocytes. Life Sciences 92 533-540. (doi:10.1016/j.lfs.2013.01.001)

Kurra S \& Siris E 2011 Diabetes and bone health: The relationship between diabetes and osteoporosis-associated fractures. DiabetesMetabolism Research and Reviews 27 430-435. (doi:10.1002/dmrr.1197)

Liang QH, Liu Y, Wu SS, Cui RR, Yuan LQ \& Liao EY 2013 Ghrelin inhibits the apoptosis of MC3T3-E1 cells through ERK and AKT signaling pathway. Toxicology and Applied Pharmacology 272 591-597. (doi:10.1210/en.2013-1298)

Ma X, Meng J, Jia M, Bi L, Zhou Y, Wang Y, Hu J, He G \& Luo X 2013 Exendin-4, a glucagon-like peptide-1 receptor agonist, prevents osteopenia by promoting bone formation and suppressing bone resorption in aged ovariectomized rats. Journal of Bone and Mineral Research 28 1641-1652. (doi:10.1002/jbmr.1898)

Matsuguchi T, Chiba N, Bandow K, Kakimoto K, Masuda A \& Ohnishi T 2009 JNK activity is essential for Atf4 expression and late-stage osteoblast differentiation. Journal of Bone and Mineral Research 24 398-410. (doi:10.1359/jbmr.081107)

Mieczkowska A, Mansur S, Bouvard B, Flatt PR, Thorens B, Irwin N, Chappard D \& Mabilleau G 2015 Double incretin receptor knock-out (DIRKO) mice present with alterations of trabecular and cortical micromorphology and bone strength. Osteoporosis International 26 209-218. (doi:10.1007/s00198-014-2845-8)

Miguel SM, Namdar-Attar M, Noh T, Frenkel B \& Bab I 2005 ERK1/2activated de novo Mapkapk2 synthesis is essential for osteogenic growth peptide mitogenic signaling in osteoblastic cells. Journal of Biological Chemistry 280 37495-37502. (doi:10.1074/jbc. M503861200)
Montagnani A \& Gonnelli S 2013 Antidiabetic therapy effects on bone metabolism and fracture risk. Diabetes, Obesity and Metabolism 15 784-791. (doi:10.5312/wjo.v5.i3.247)

Nuche-Berenguer B, Lozano D, Gutierrez-Rojas I, Moreno P, Marinoso ML, Esbrit P \& Villanueva-Penacarrillo ML 2011 GLP-1 and exendin-4 can reverse hyperlipidic-related osteopenia. Journal of Endocrinology 209 203-210. (doi:10.1530/JOE-11-0015)

Nuche-Berenguer B, Moreno P, Esbrit P, Dapia S, Caeiro JR, Cancelas J, Haro-Mora JJ \& Villanueva-Penacarrillo ML 2009 Effect of GLP-1 treatment on bone turnover in normal, type 2 diabetic, and insulinresistant states. Calcified Tissue International 84 453-461. (doi:10.1007/s00223-009-9220-3)

Nuche-Berenguer B, Moreno P, Portal-Nunez S, Dapia S, Esbrit P \& Villanueva-Penacarrillo ML 2010a Exendin-4 exerts osteogenic actions in insulin-resistant and type 2 diabetic states. Regulatory Peptides 159 61-66. (doi:10.1016/j.regpep.2009.06.010)

Nuche-Berenguer B, Portal-Nunez S, Moreno P, Gonzalez N, Acitores A, Lopez-Herradon A, Esbrit P, Valverde I \& Villanueva-Penacarrillo ML 2010b Presence of a functional receptor for GLP-1 in osteoblastic cells, independent of the cAMP-linked GLP-1 receptor. Journal of Cellular Physiology 225 585-592. (doi:10.1002/jcp.22243)

Pacheco-Pantoja EL, Ranganath LR, Gallagher JA, Wilson PJ \& Fraser WD 2011 Receptors and effects of gut hormones in three osteoblastic cell lines. BMC Physiology 11 12. (doi:10.1186/14726793-11-12)

Pereira M, Jeyabalan J, Jorgensen CS, Hopkinson M, Al-Jazzar A, Roux JP, Chavassieux P, Orriss IR, Cleasby ME \& Chenu C 2015 Chronic administration of Glucagon-like peptide-1 receptor agonists improves trabecular bone mass and architecture in ovariectomised mice. Bone 81 459-467. (doi:10.1016/j.bone.2015.08.006)

Sancho V, Nuche B, Arnes L, Cancelas J, Gonzalez N, Diaz-Miguel M, Martin-Duce A, Valverde I \& Villanueva-Penacarrillo ML 2007 The action of GLP-1 and exendins upon glucose transport in normal human adipocytes, and on kinase activity as compared to morbidly obese patients. International Journal of Molecular Medicine 19 961-966.

Sanz C, Vazquez P, Blazquez C, Barrio PA, Alvarez MD \& Blazquez E 2010 Signaling and biological effects of glucagon-like peptide 1 on the differentiation of mesenchymal stem cells from human bone marrow. American Journal of Physiology: Endocrinology and Metabolism 298 E634-E643. (doi:10.1152/ajpendo.00460.2009)

Viegas M, Costa C, Lopes A, Griz L, Medeiro MA \& Bandeira F 2011 Prevalence of osteoporosis and vertebral fractures in postmenopausal women with type 2 diabetes mellitus and their relationship with duration of the disease and chronic complications. Journal of Diabetes and its Complications 25 216-221. (doi:10.1016/j.jdiacomp.2011.02.004)

Xie J, El Sayed NM, Qi C, Zhao X, Moore CE \& Herbert TP 2014 Exendin-4 stimulates islet cell replication via the IGF1 receptor activation of mTORC1/S6K1. Journal of Molecular Endocrinology $\mathbf{5 3}$ 105-115. (doi:10.1530/JME-13-0200)

Yamada C, Yamada Y, Tsukiyama K, Yamada K, Udagawa N, Takahashi N, Tanaka K, Drucker DJ, Seino Y \& Inagaki N 2008 The murine glucagon-like peptide-1 receptor is essential for control of bone resorption. Endocrinology 149 574-579.

Yamada Y 2012 [Diabetes mellitus and osteoporosis. Incretin as a coordinator of glucose and bone metabolism]. Clinical Calcium 22 1353-1358.

Zhou H, Yang X, Wang NL, Zhang Y \& Cai GP 2007 Tigogenin inhibits adipocytic differentiation and induces osteoblastic differentiation in mouse bone marrow stromal cells. Molecular and Cellular Endocrinology 270 17-22. (doi:10.1248/bpb.30.279)

Received in final form 24 November 2015

Accepted 2 December 2015

Accepted Preprint published online 8 December 2015

Published by Bioscientifica Ltd. http://jme.endocrinology-journals.org

DOI: 10.1530/JME-15-0264
๑) 2016 Society for Endocrinology Printed in Great Britain 